\title{
LAND USE IN THE KARSTIC LANDS IN THE MEDITERRANEAN REGION
}

\author{
Ibrahim Atalay
}

\begin{abstract}
Karstic lands have special importance in terms of soil formation and land-use. Soil appears only on the flat and slightly undulating karstic lands, while soils are found along the cracks and bedding surfaces between the layers on the hilly karst areas although these lands are rocky in appearance. Karstic lands in the hilly area are not conducive to cultivation. But rocky areas create a favourable habitat for the growth of forests except in an arid climate. Because the tree roots easily follow and develop along the cracks in the limestone. As a general rule soil erosion does not occur on sub-horizontal karst surfaces due to the fact that atmospheric waters easily infiltrate along the cracks. Natural generation of vegetation like the maquis-type occurs via the root suckers, but coniferous trees such as cedar, fir, pine through seed dispersal.

The clearance of natural vegetation on the karstic lands leads to the formation of bare lands. That is why the slopes of the limestone hillsides have been converted into bare and/or rocky terrains in places where natural vegetation has been completely destroyed.
\end{abstract}

KEY WORDS: soil formation, land use, land degradation

\section{Introduction}

Parent material is one of the main ecological factors which determines the soil formation and the growth of natural vegetation. Limestone which is a chemical sedimentary rock mainly composed of calcium carbonate, produces particular topographic forms. The soil forming process and the ecological conditions of a limestone area are different than in areas with other parent materials. In order to explain the importance of the limestone on land-use it is necessary to give a brief description of the soil formation and ecological conditions that are relevant to this type of area .

\section{Materials and methods}

Detailed field studies have been carried on in the region since 1970. Soil profiles and parent materials were examined in different places extending from the seashore to the subalpine belt in the Mediterranean Region of Turkey and in some other Mediterranean countries. The experimental plots were selected with different parent materials and altitudes in order to observe the regeneration of vegetation with particular reference to the degraded areas. Field observations were also made in the forest fire areas.

\subsection{Soil formation in the karstic lands}

Limestone which is mainly composed of calcium carbonate and clay is dissolved 
by water containing carbon dioxide. Karstic topographic forms such as lapiés, karstic depressions (dolines, poljes), sinkholes and ground water channels formed through the dissolving of the limestones. Soil material in the karstic areas is of clay which is the main remaining material after the removal of calcium carbonate. For this reason the soil which is found in the karstic land is of 'clayey' texture.

Tree roots easily penetrate into the deeper part of fractured rocks. This suggests the presence of favourable ecological conditions for soil formation. Root residues, producing organic acids, may also be effective in chemical weathering. Soil formation in the karstic lands, on the other hand, is mainly determined by the limestone purity, situation of the cracks and inclination of the beds.

The thin bedded limestones produce richer soils than the massive rocks. This is because these types of limestone are good water retainers (Fig.1). For instance, red Mediterranean soils (Terra-rossa or Alfisol) are abundantly found on the thin bedded and fractured limestones. While in the Taurus Mountains on massive and hard lime-

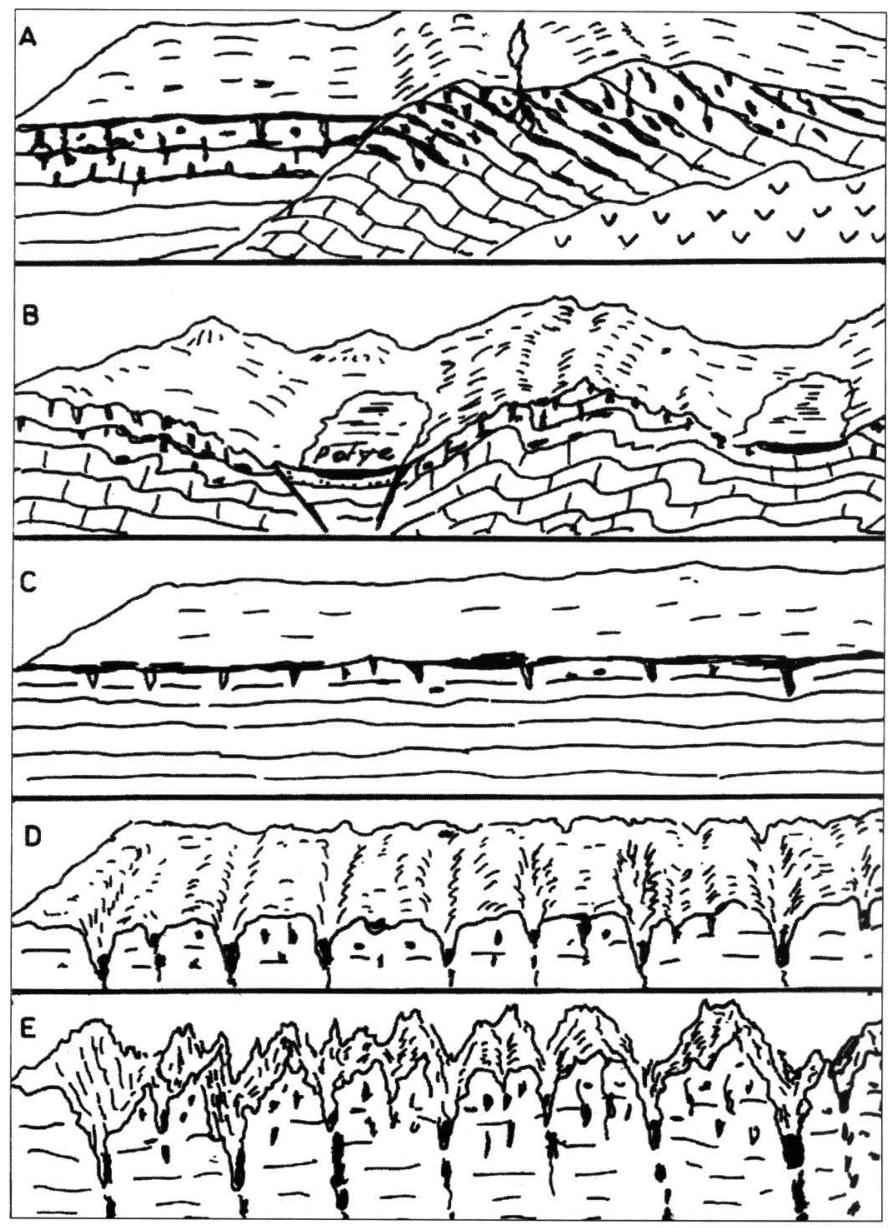

Fig. 1 - Soil formation on the karstic lands: A Development of the soils along the cracks and in the cavities between the beds; $B$ Formation of soils along the cracks in the rugged karstic lands and karstic depression; C - Beginning of the soil formation along the cracks on/in of the horizontal limestone layer; $D$ - Vertical transportation of the soils with the widening of the cracks; E - Formation of the rugged karstic lands dissected by lapiés and transportation of the soil towards the deeper parts with progression of karstification. 
stones the soils are thinner (Atalay, 1997b).

The dissolution of limestones along the vertical fractures leads to the widening of fractures, this process is very well expressed in the Mesozoic limestones in the Alpine mountains extending in the northern part of Mediterranean Sea (Fig. 1).

Soils which developed along the fractures, have been transported vertically by a widening of the fractures via dissolution of the limestones. Thus, the soil mass may be removed from the near surface to much deeper zones by vertical transportation with time. Such soils, in general are red and completely decalcified. This explains why soils are found in the fillings of caves and of karstic depressions.

Thin fractures and bedding planes are favourable sites for water retention. Therefore the process of weathering and soil formation take place in locations where water is held. The tree roots penetrate easily into the deeper part of the rocks through the fractures and accelerate soil formation.

Soil erosion processes generally do not occur on the surfaces of the karstic lands because of the fact that the run-off is very low and the rock has a high infiltration capacity.

The fractures in the limestones provides suitable conditions for oxidation so that through Fe oxidation soils attain a reddish colour.

Rich and thick soils are common in the places where a thin bedded stratigraphic sequence is present. Because pure limestones sometimes contain many more fractures than the 'clayey' limestones, soil formation takes a long time, and most of the soils do occur in widened fractures, even a few meters below the rock surfaces, therefore most of them are paleosoils (Atalay, 1997a and 1997b).

\subsection{Ecological properties of the karstic lands}

Karstic lands are where the main productive forests are found in the Mediterranean climatic region. The cation exchange capacity of karstic soils is about $40 \mathrm{me} / 100 \mathrm{~g}$ soil. This figure is sufficient for the growth of forests. These soils contain the required nutriments for plants. Plant roots easily develop and grow along the fractures. Water retention capacity is also high due to the 'clayey' texture of the soils. Water wastage through evaporation and capillarity is very low in the soils found in the fractures.

The inclination of the slope has no significant effect in karstic lands due to the fact that soil erosion is not always very intensive. In the virgin karstic lands the slopes are covered by natural vegetation. These areas are widespread in the Taurus Mountains. While damaged hillside areas which are composed of granite, gneiss, andesite appear as a barren areas.

The seeds which fall down into the cracks containing soil germinate easily and the plant roots follow the water seepage through the cracks. The roots reach up to about 1 meter in length in only one vegetatiive period (Atalay, 1987b). These properties produce favourable conditionsfor the growth of vegetation. Indeed the virgin karstic areas are covered by dense forest. For example in the Euro-Mediterranean belt of the Taurus Mountains the red pine (Pinus brutia) is prolific and the upper slo- 
pes of these mountains are covered by cedar (Cedrus libani), black pine (Pinus nigra) and fir (Abies cilicica). Studies on the forest biomass on the different parent material such as limestone, marl, sandstone, schistes and ultrabasic rocks, show that the karstic land is one of the most favourable for the growing areas of these forests (Atalay, 1994, 1995).

\section{Vegetation in Mediterranean karstic lands}

Agricultural activities and forestry on the karstic lands are governed by altitude and soil properties.

As a general rule arable lands are only found in the karstic depressions mostly within the karstic plains (poljes). These lands have reddish Mediterranean soils which have formed both in situ and alluvial and colluvial soil materials which derive from the uplands in the vicinity of karstic terrains. Arable lands are devoted to crop production. Subtropical crops such as orange, vegetables and fruits are produced in the lower belt of the Mediterranean Region. While cereals grow in the upper and/or oro-Mediterranean belt. Olive groves are also widespread on the karstic terrains. Wild olive trees which are found in the lower belt of the Mediterranean region have been grafted.

Two main tree communities grow in the karstic lands:

1- Most of the karstic lands are covered by maquis or shrub communities which are the climax species for the Mediterranean Region, in general. Maquis is accepted as a secondary succession in subhumid and humid parts of the region (Atalay, 1994). Indeed the maquis is widespread for example in places where Pinus brutia (red pine) forests have been destroyed.

This type of vegetation mainly regenerates via root suckers even if completely cleared. For example, the roots of maquis elements like Laurel (Laurus nobilis), Kermes oak (Quercus coccifera), Eastern strawberry tree (Arbutus andrachne), Pistache (Pistacia terebinthus), wild olive tree (Olea europea) etc. develop along the fractures of the limestones. It is impossible in general to dig up the roots of these shrubs. On the other hand if the roots of the maquis is cut and/or wounded, the plant regenerate easily with the young shoots. For this reason maquis vegetation is the most widespread in the karstic lands with a Mediterranean climate and the semiaridsubhumid parts of the World.

2- Some coniferous trees such as Pinus nigra, Pinus pinea, Pinus brutia, Cedrus libani, Abies cilicica and broad-leaved trees such as Fagus, Castanea, Alnus sp. etc. also grow in the karstic lands. These trees regenerate with natural seedlings. If these forest trees were completely cleared, bare or rocky areas would appear. In other words, if cedar and black pine forest had completely vanished, the karstic lands would be converted into rocky barren lands. Indeed the upper karstic part of the Taurus Mountains resembles the stony desert areas due to the destruction of the natural vegetation. Natural regeneration of the forest could only happen in the areas protected from intensive grazing in the vicinity of the forests. 
Tree seeds fall down into the cracks containing soil, germinate and after one or two years, the forest commences to spread slowly. Indeed the cedar forest which is found in the protected areas has begun to spread (Atalay, 1987b, 1995; Boydak and Ayhan, 1990; Boydak, 1996). One can see these forest areas in the upper part of the Taurus Mountains. If there are no tree communites forests, karstic land remain bare land (Fig. 2). In this case the reforestation of the karstic lands is generally impossible because of the fact that there is insufficient soil on the surface for the plantation of plants. Most of the karstic bare land in the Taurus Mountains have arisen as the result of forest destruction.

One of the main reasons for the destruction of the natural vegetation in the karstic lands is over-grazing: the economic activities of the rural areas depend on both crop production and animal husbandry. The animal husbandry activities change according to vegetation belts. Evergreen maquis vegetation also provides meadow

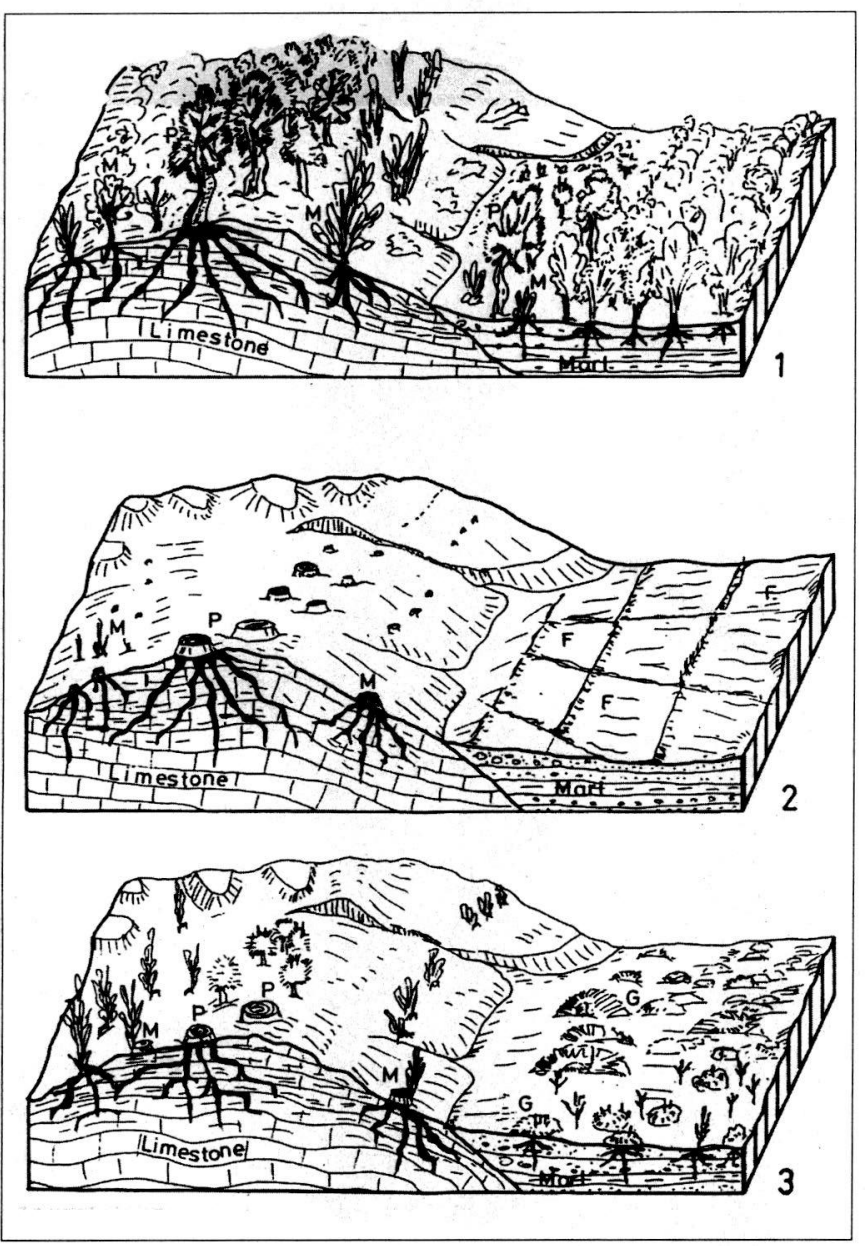

Fig. 2 - Erosion and land degradation in the Mediterranean vegetation in the karstic lands and marl deposits: 1 - Natural vegetation; 2 - Clearance of vegetation; 3 - Regeneration of maquis with root suckers in the karstic land and garrigue dominance on the abandoned farmland. ( $P=$ Pinus brutia , $M=$ Maquis, $G=$ Garrigues, $F=$ Farmland). 
areas especially for goats in the lower belt of the region. The evergreen maquis vegetation in the karstic lands form the main grazing areas for goats.

Nomadic activities, on the other hand, are also the main reasons for erosion and land degradation. Nomadic societies, named Yörüks (walking men) in Turkey, graze their animals during the winter season on the coastal belt of the Mediterranean and Aegean seas. During the summer, Yörüks travel up to the Taurus Mountains in order to graze their animals.

As a result, this type of animal husbandry has led to the degeneration of the natural vegetation and the disappearance of the forests. In other words, grazing in the forest lands hinders natural regeneration since young plants are eaten by the goats. In addition, the natural regeneration of the forest in the burnt areas does not occur where the animal grazing continues. On the other hand both the upland meadow areas of the Taurus Mountains and oro-Mediterranean forest belts are also summer grazing areas for Yörük societies and the rural population. In these areas excessive exploitation of forests and animal grazing have led to the degeneration of the composition of natural forests and herbaceous vegetation. Indeed, oro-Mediterranean forests composed of Cedrus libani, Abies cilicica and Pinus nigra are replaced by the steppe and juniper communities due to human impact.

These activities which have continued for centuries have led to the degradation of the climax vegetation. Because of continuous destruction, the upper limits of the forest have shifted one or two hundred metres from the natural timber line, and most part of the oro-Mediterranean forests have disappeared. For example the oroMediterranean cedar forest areas have been replaced by stony barren land. Some parts of the forest areas are occupied by juniper communities which can be termed a regressive succession (Atalay and Semenderoglu, 1996). A large majority of the climax herb vegetation has disappeared due to over-grazing . For example, subalpine herbs have been replaced by the spiny cushion species such as Acantholimon, Astragalus, and bitter herbs such as Euphorbia species which are not eaten by animals. This has also caused a decrease in herb production. So the upper parts of the oro-Mediterranean forest area have been converted into stony barren lands. These lands cover an area of 1 million hectares.

\section{Results}

Some conclusions can be reached regarding land degradation and erosion given the particular habitats of the Mediterranean Region:

1 - Hilly karstic lands which are not favourable to agriculture are the main areas of the natural vegetation. Most of the burnt and cleared areas are covered by maquis vegetation in the semi-arid part of the Mediterranean region. Even if maquis or shrubs are cleared in karstic land, regeneration occurs due to root sucking.

2 - The regeneration of the coniferous forest trees is prevented in general if all trees have been cleared. For this reason destroyed forest areas have been converted into bare rocky land. 
3 - Rocky karstic bare lands have arisen as the result of forest destruction and over-grazing.

4 - It is necessary to protect the area from over-grazing and excessive forest exploitation in order to maintain the natural equilibrium and a sustainable development of the karstic hillside areas.

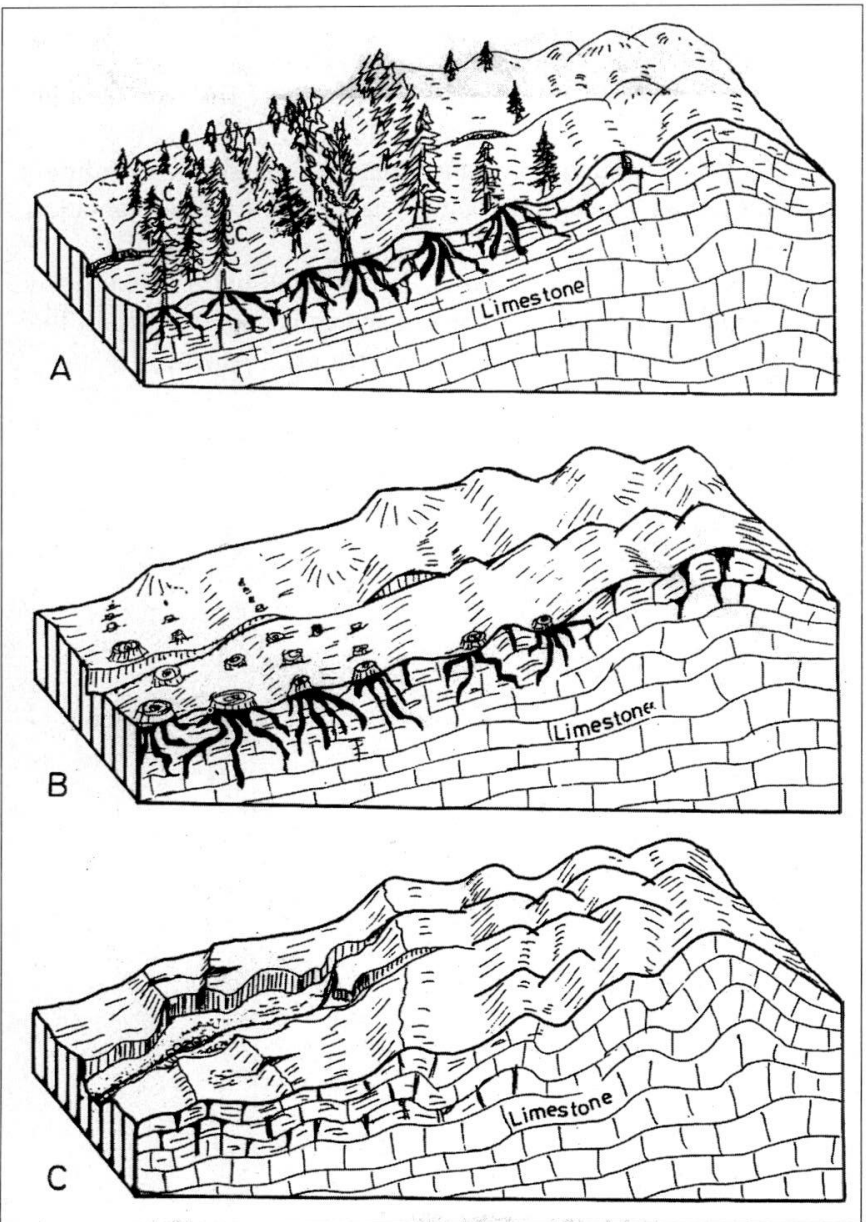

Fig. 3 - Land degradation in the karstic land of the upper belt of the Taurus Mountains: A Natural vegetation (Cedrus libani forest); $B$ - Complete clearance of cedar forest ; $C$ Formation of bare land.

\section{REFERENCES}

ATALAY I., 1987a. Introduction to geomorphology of Turkey, Aegean Univ Pres, Izmir.

ATALAY I., 1987b. The ecological conditions of natural occurrence areas of cedar (Cedrus libani A. Rich.) and regioning of seed transfer of cedar in Turkey. General Directorate of Forest, Pub No. 661/63 Ankara.

ATALAY I., 1989. Soil geography (in Turkish). Aegean Univ. Press, Izmir.

ATALAY I., 1994. Vegetation geography of Turkey. Aegean Univ. Press, Izmir.

ATALAY I., 1995. Pedogenesis and ecology of karstic lands in Turkey. Acta Carsologica, 
XXIV: 53-67.

ATALAY I., 1996. Effects of the parent materials of soils on the land degradation in Turkey. Intrnational Conference on land degradation, Programme, Abstracts and Excursion, Adana.

ATALAY I. and SEMENDEROGLU A., 1996. Regressive and progressive succession of the Mediterranean vegetation. 27th Geographical Congress, Abstracts, Hague, The Netherlands.

ATALAY I., 1997a. Geography of Turkey, Aegean Univ. Press, Izmir.

ATALAY I., 1997b. Red Mediterranean soils in some karstic regions of Taurus Mountains, Turkey. Catena, 28: 247-260.

BOYDAK M. and AYHAN S., 1990. Anamur yoresinde ciplak karstik alanlarin sedir ekimiyle agaclandirilmasi (The reforestation of the bare karstic lands with cedar plantation). Ormancilik Aras. Enst. Derg. 36 (1): 7-21.

BOYDAK, M. 1996. Toros sedirinin (Cedrus libani A. Rich.) ekolojisi, silvikültürü ve dogal ormanlarin korunmasi (Ecologic, silvicultural properties and protection of natural forest of Taurus cedar (Cedrus libani A. Rich). Forest Ministry Pub. Nu. 012, Ankara, 78 pp. 